\title{
Alevi politics in contemporary Turkey
}

\section{Tahire Erman \& Emrah Göker}

To cite this article: Tahire Erman \& Emrah Göker (2000) Alevi politics in contemporary Turkey, Middle Eastern Studies, 36:4, 99-118, DOI: 10.1080/00263200008701334

To link to this article: https://doi.org/10.1080/00263200008701334

Published online: 07 Dec 2006.

Submit your article to this journal $\pi$

LII Article views: 695

Citing articles: 30 View citing articles 저 


\title{
Alevi Politics in Contemporary Turkey
}

\author{
TAHİRE ERMAN and EMRAH GÖKER
}

In this article we attempt to cast light on Alevi politics in Turkey, mainly the diverse political orientations regarding Alevilik.' We note the differential political power the groups with different political orientations hold and their varied positionings $v i s-\grave{a}$-vis the Turkish state, as well as the competing political agendas they offer, and to which groups in the Alevi public these political agendas appeal and why. Alevilik is the second major religious formation after Sunnilik in Turkish society. There is no accurate information and consensus on the number of Alevis in the society because of the assimilative politics of the state since Ottoman times, as well as the tendency of the Alevi to hide their identities. Their estimated number by different sources however ranges from at least 10 per cent to over a quarter of the total population. ${ }^{2}$ Since the last decade Alevis have become more visible in society, and they have been more active in the political arena. We can talk about the re-politicization (for some, revivalism) ${ }^{3}$ of Alevilik in the Turkish civil society where the popular and academic literature on various aspects of Alevilik increased. ${ }^{4}$ Political debates initiated by various Alevi communities and popular demands of the Alevi population were carried onto the public sphere. With the development of and quantitative increase in the media in Turkey, Alevi identities found new channels to express themselves.

General reasons for this re-politicization of Alevilik can be identified: ${ }^{5}$ Firstly, there is the fall of Communism and its effect on those Leftists close to Alevilik. This resulted in the redefinition of Alevilik as an alternative social movement (and clearly not a religious one). Secondly, the rise of Sunni political Islam has made the Alevi population, along with Sunni Kemalists, organize themselves as a counterforce against it, defending Kemalist principles, and particularly secularism. This point is also addressed by Kehl-Bodrogi who argues that the timing of the reawakening of Alevism was no coincidence:

(The reawaking of Alevism) occurred at the peak of the political struggles to preserve the laicistic legacy of Kemalism. In this situation the Alevis were in a position to present themselves to secular Turkey 
as a natural stronghold against Islamism and as 'guarantors of laicism.' Indeed, the secularist circles had from the outset regarded Alevism, which presented itself as progressive, religiously tolerant and democratic, as their closest allies. ${ }^{6}$

Moreover, there is the 'Kurdish problem', and the military confrontation between the PKK (the Kurdistan Workers Party) and the Turkish forces, which increased the politicization of ethnic groups. The forced migration from eastern regions mostly to gecekondu (squatter) neighbourhoods in metropolitan cities increased the tension in the urban context. ${ }^{7}$ Being a Kurd today bears the stigma of being a separatist, a collaborator of the 'enemy', frequently mentioned in the media as the murderer of babies. Under these circumstances, Kurdish Alevis have turned towards the religious elements of their ethnicity, stressing their Aleviness in public discourse. ${ }^{8}$

We should also add the political and economic aspects of late modernization and social change which Turkey is experiencing, such as the publicization and politicization of Alevi 'difference' through the newly developing media services, and the funding of powerful Alevi associations by the Alevi members of a newly growing urban elite. Thus, we should acknowledge the role of the media and Alevi organizations in the repoliticization of Alevilik.

In this context, we can argue that the re-politicization of Alevilik in the 1990 s is qualitatively different from the pre-1980 politicization of Alevis as part of a Socialist movement. Before the 1980 coup, although the religious and ethnic aspects of Alevilik were also used for marking the difference between MHP's (the Nationalist Action Party) Sunninationalists and between the radical Islamists, the main 'binding force' of the politicized Alevi identity was class. Although there were various orthodox Marxist groups with differing strategies, in general they tended to resort to the ahistorical, class-accentuated use of the cultural and historical content of Alevilik in order to gain the populist support of the subaltern Alevis, especially of the poor peasants and the urban poor. Following Krisztina Kehl-Bodrogi, ${ }^{9}$ we argue that in the contemporary context, in a Turkey trying to ally with neo-liberalism and to establish a relatively organized market economy (and in a world which witnessed the 'collapse of Communism' as practiced in the former Soviet Union), rapidly urbanizing Alevi communities have come to mark their identities more with cultural and religious definitions, many of them criticizing the 'strong class emphasis' of the pre-coup era: ${ }^{10}$ while those who do not, and they are a minority, feel the need to suppress the class dimension for now. 
Furthermore, the dynamics of late modernization, especially urbanization, have threatened the traditional ethno-religious characteristics of Alevilik:

With the opening up of the closed parochial communities and the migration of their members to the big cities, the orally mediated and simple folk-beliefs of the Alevi are confronted by an outside world which cannot be integrated into their traditional religious parameters. The Alevi's narrow social basis of tribe and village communities, and their isolated conditions of life, resulted in a mystic world-view which failed to objectify itself in a widespread written tradition. ${ }^{\prime \prime}$

The decline of traditional religious services and archaic Alevi rituals and institutions is a point also made by Alevi academics..$^{12}$ And this has led to the attempts to restructure the Alevi religion and culture in the urban context, resulting in emphasis on the religious and cultural aspects of Alevilik.

However, this should not lead us to think that class issues in contemporary Alevi politics are no more valid. We can talk about Alevilik as a resource of urban survival in maintaining an 'extra-state welfare system' through informal networks and clientalism. ${ }^{13}$ Thus contemporary repoliticization of Alevilik may also be read as a reconstructive, modern and urban response to deepening class inequalities. Against the claims that in the radically diversified world of conflicts, class identities are obsolete, Ayşe Ayata, for example, draws attention to a significant class dimension in the case of Alevis:

Since the 1980s, (Alevis) have been experiencing downward mobility politically and economically. The significance of the unionized working class has declined parallel to the decline in the wages, so they are economically worse off as a social group. Now a new dimension has been added to this downward mobility trend; since a large number were employed by Social Democratic municipalities, their jobs are often threatened or taken away by the new right-wing incumbents. ${ }^{14}$

Thus the 'extra-state welfare system', in the case of Alevis, is facing a serious problem. Being an Alevi today rarely contributes to class mobility in the case of the service or industrial workers and the new migrants to big cities. It may even hinder it in certain cases, given the institutional and political (as well as social) Sunni bias against Alevis. This may increase the radical politicization tendencies in this group of economically disadvantaged Alevis. The Gazi event in Istanbul (1995) is a recent example of the class-based revolt of Alevis. ${ }^{15}$ 
In brief, while structurally there certainly is a class dimension to contemporary Alevi re-politicization, actual Alevi politics manifests itself through a 'politics of recognition' where the demands of various Alevi groups are voiced in order to have equal participation in all spheres of life without facing discrimination, especially in their relations with the Sunni population. In this 'politics of recognition', different Alevi groups have emerged with different claims on Alevilik. In the following section, we elaborate on the contemporary Alevi politics in Turkish society through its rival groups, popular debates, inner dynamics and connections with the more general power struggle. Our focus here is on different Alevi movements in politics, and not on cultural and/or religious differences among the Alevis which range from Tahtacilar to Bektashis. While doing so, we first cover the Alevilik in the literature as a significant means of shaping the Alevi political orientations.

The late 1980s can be marked as the period when the first popular and academic works began to appear, and the first debates were heard (or read) in the media. After 1990, both in Europe and in Turkey, Alevi (Turkish and Kurdish) cem houses, organizations, associations and federations began to flourish, most having sub-branches of literary or other specific societies. The Alevi Manifesto, which was written in March 1989 and published for the first time in February 1990, can be considered as a significant landmark in the re-politicization of Alevilik in post-coup Turkey. It was written collectively and signed by numerous intellectuals (Alevis and Social Democratic Sunnis), academics, authors and journalists. The manifesto begins with the following opening statement:

This manifesto aims to make the problems of Alevilik, a branch of Muslimhood living in Turkey, known and to inform the public with the demands of Alevis. Alevis see other beliefs as 'true, beautiful, sacred'. However, they expect a similar positive sense and approach towards their own faith and culture ... The recognition of the Alevi taught will be a source of peace and prosperity for Turkey. ${ }^{16}$

The manifesto goes on to call for the acceptance of the difference of the Alevi faith and culture, equal representation and opportunities in education, in the media and in receiving their own religious services. It further emphasizes that Alevis have always supported and do still support the principles and reforms of Atatürk, and Sunni people are called to learn more about Alevis and to get rid of their biases.

With this text the Alevi identity made its first influential public appearance. Although the manifesto implied that there was one single 
Alevilik and a unified Alevi people, which is highly disputable, the text was nonetheless important since it was received very positively by the intellectual community, and it later lured many non-religious or even Sunni sympathizers into contributing to the growing Alevi literature. Today there exists a small 'library' of Alevi literature, and as Olsson implies, this shows the eagerness of Alevi communities to know about their identities and to produce historical and political claims about them:

Among the rights claimed by minorities like the Alevi is the right to write down their own version of history ... By writing or telling one's own history an imagined community of an idealized past is constructed, and even conjured up, into which the needs and wishes of all present are projected. Like genealogies and origin myths, the telling of history provides meaning, experience of identity, and visibility. Hence, historiography creates mutually conflicting histories which are used and abused to justify politically controversial issues, such as claims on land and independence. ${ }^{17}$

Popular works on Alevilik are many, and they mainly deal with a number of common themes: Alevi religious teachings, rituals, folklore, the nature of Alevi religious institutions such as cem or musahiplik, and the like. Almost all of such works give a brief history of Alevilik, and depending on the writer's political intentions, these histories vary: Sometimes the cult of Ali is highly praised, sometimes various social uprisings in Selcuk and Ottoman history are emphasized, or the writer may try to justify his or her case by focusing on a certain personality, like Pir Sultan Abdal or Hacı Bektaş Veli. The target population is either the large number of ordinary Alevis who do not have access to knowledge about Alevi religious practices and who, in the official education system, cannot learn anything about Alevilik, or the mass of Sunni readers who do not know anything about Alevilik (or else do but have biased knowledge).

The authors of popular works are sometimes Alevi religious leaders (dedes or dede-babas, or descendants of them) with a significant amount of religious and historical knowledge on the specific Alevilik they have faith in. A very common practice is the supplementation of the texts by tasavvuf (sophism), Alevi, or Bektashi poetry, religious prayers, excerpts from the Koran or from Ali's or Muhammed's sayings. Although they are less in number, there are also popular works by Sunni religious people ${ }^{18}$ and nationalists, ${ }^{19}$ whose target population is the large Sunni and patriotic communities. These latter works and most of the likes of them are propagandist works which supply the reader with misleading information, 
tending to reproduce already-existing Sunni biases against the Alevi faith. On the other hand, some of the popular Alevi works may also be manipulating and usually assume an anti-Sunni rhetoric when they talk about the injustice done to Ali and his family after Muhammed's death, or when they tell about the Sheikh Bedreddin revolt.

Marxist-oriented populist works ${ }^{20}$ in this category share a common theme of equating the historical oppression of Alevi communities (and even pre-Alevi uprisings like Babai revolts of the Selcuk era) with class struggle (the Sheikh Bedreddin case, for example), and Alevilik with popular socialism. These works are fewer in number when compared to those which merely inform about the historico-religious aspects of Alevilik.

Rival 'popular' Alevi groups are more or less apparent in the literature: Kurdish Alevi populists, Social-Democratic Alevis, more religiously conservative Alevis, Alevis emphasizing patriotism, and the like. On the whole, we may say that while the Alevi identity (whatever form it takes according to the political standpoint of the writer) is strengthened through this popularization via books in circulation, the majority of the popular works do not establish any links between the traditional-religious dimension of Alevilik and the changing, transforming processes in contemporary society.

In contrast to popular works, journalistic works, aside from those numerous serial articles printed in dailies, are not many in number. ${ }^{21}$ Similar to popular works, these works also include summaries about common Alevi rituals and institutions, who is Ali, what do Alevi dedes do, and so on. Different from the first category, we encounter here as many non-Alevi intellectuals and journalists (usually Left-oriented, even non-practicing Sunnis) as Alevi ones. The political dimension, different from popular works, is more carefully introduced in these works. We are introduced to a more comprehensive analysis of the oppression of Alevi people in Ottoman and Republican times, learn how and why the socialist discourse is related with Alevilik; or we are told, in a less populistic manner, how Alevis embraced Kemalism in the 1920s and how they establish a 'popular front' against the radical Sunni 'threat' today.

In addition, sociological-anthropological studies ${ }^{22}$ and historical studies ${ }^{23}$ on Alevilik have been conducted by academics, and Alevis have mainly been studied, for example in relation to migration, gecekond $u$ life, urbanization, ethnicity, and social conflict. There are fewer Alevi intellectuals in this category, and a very small number of such books are publicly read (most of the academic work is in foreign languages).

In brief, we can say that although 'written Alevilik' does not directly 'agitate' the Alevi believer, it provides easy access to a cultural and 
historical legacy of Alevilik: legends, tales, poetry, religious practices. All this accumulation of knowledge helps justify the existence of a particular Alevi identity. We now turn to Alevi political groups (and groups having claims on Alevilik) and to the significant public debates concerning Alevilik.

A number of academics have tried to distinguish the main 'schools' within Alevi politics. Bilici, ${ }^{24}$ for example, points out four such groups: (a) LeftAlevism, using Alevi teachings as a 'liberation theology' much like the way Latin American popular Marxism used Catholicism; (b) Mystical-Islamic Alevism, which is organized around Hacı Bektaş Veli associations, supporting a more solipsist, individualist Islam and emphasizing the theme of 'love'; (c) Centre-Alevism, politically Social-Democratic or liberal, represented by the powerful Cem Vakfi; and (d) Shii-inclined Alevism, more fundamentalist and conservative, supporting the cause of Iranian Shiism and interpreting Alevism within the Twelve Imams doctrine. Another distinction between the different 'schools' in Alevism is made by Ocak ${ }^{25}$ as follows: (a) Kemalist-humanist approaches, (b) Sunni-Islamist approaches, (c) Marxistliberationist approaches, and (d) Turkish-nationalist approaches. In the following section we expand on our own classification, briefly discussing the way each group politicizes its particular 'Alevilik'. The groups we cover are not static communities with clearly defined boundaries, but rather dynamic political locations where certain critical views and sometimes organizations ally. We begin from the politically least influential group and move towards the most powerful.

The very marginal 'Iranian Shiite Alevilik' group comes from a strictly conservative, highly religious background of Iranian Shiism. The 'militants' of this group are mainly trained politically and religiously in the Islamic Republic of Iran, sent to Turkey for the purpose of spreading their teachings among Alevis. Organized around mosques like Ehl-i Beyt Mosque (Çorum) and Zeynebiye Mosque (İstanbul) and around periodicals like Ondört Masum and Assure, they advocate that Alevilik should reinvoke Islamic Sharia principles, reminding everyone that Shiism has also devcloped on the Ali and the Twelve Imams cult. ${ }^{26}$ They claim that, because of the long years of Ottoman rule and then of the Turkish Republic, Alevilik could never find the chance to return to its roots, it was corrupted, and the believers were made to forget their true Shiite past.

Interestingly, this group's ideas about Bektashism are in line with some of the Marxist interpretations. According to Shiite Islamists, 
Bektashism was founded by the Ottoman rule to prevent the spread of Shiite ideas among Alevis during the threatening years of the Sheikh Ismail and Shiite dervishes. Urban Bektashism (even called 'collaborators with the ruling class' in some Marxist texts on Alevilik) was used against the doctrines of the Twelve Imams. The group is totally against the practice of cem and other similar Alevi rituals, seeing them as part of the Bektashi tradition, and they call all Alevis to mosques, to obey the orders of Koran and to practice namaz. Moreover, they interpret the TurkishIslamic synthesis as fascism. Their teachings, on the whole, rely totally on old religious works. They try to articulate their Shiite teachings with existing Alevilik. Some of the members of the group have close ties with extremist groups like Hizbullah, preaching armed struggle against the 'infidel rule' in Turkey. ${ }^{27}$

'The basic thesis of this group [Mystical-Islamic Alevilik]', Bilici writes, ${ }^{28}$ 'which is assembled more particularly around the Hacı Bektaş Veli associations and lodges, is to view Alevi religious devotion and the love of God from the point of view of the "individual"'. Feeding mainly from the Sufi tradition, the stress is more on love, passivism and solipsism. The individual believer's direct relationship to Allah is priorized.

The group is small compared to the Pir Sultan Abdal or the Cem Vakfi groups, but there is a wide variety of Hacı Bektaş organizations. Following Ocak, ${ }^{29}$ we can say that the economically better-off associations are quite traditionalist and conservative, and may have Sunni tendencies, for example, preaching that Hacı Bektaş Veli was a Sunni theologian and a religious personality. On the other hand, Hacı Bektaş Veli is seen by some others as a mythical, holy religious figure, including both the majority of Alevis and some Sunni Sufists. This group represents more the orthodox Turkish Sufist tradition rather than the heterodox Sufist tradition later claimed by Bektashism.

Politically, the group is almost insignificant. Various associations devoted to the patron saint, however, may serve as discursive resources in order to justify other groups' claims for Alevilik. For example, certain ceremonies or symposiums concerning Hacı Bektaş Veli may be the sites of 'reaffirming' the saint's Sunni or Alevi ties.

The 'Ultra-Nationalist' approach can be considered more as a kind of reaction rather than as an alternative Alevilik. However, we should bear in mind that a certain ultra-nationalist branch, naming itself the Nationalist Alevi Youth as a branch of MHP's (the Nationalist Action Party) youth 
organizations, feeds upon anti-Kurdish propaganda in society. Some of the versions of this reaction bear highly Sunni overtones, claiming that the Alevi-Sunni division is artificially created by traitors, terrorists and Communists in order to push the nation towards anarchy and disintegration. There should be no religious disputes, they say, since we are all Turks and Muslims under one Flag. Nevertheless, according to this group, contemporary Alevilik is a non-Islamic diversion that should be reintegrated into Sunnism.

Some nationalist interpreters of Alevilik strongly stress the Shamanist/ ancient Turkic legacy within Alevi syncretism and claim that Alevilik was a 'Turkmen Sunnism' formed during the era in which Turks were newly accepting - or being forced to accept - Islam. Gradually, according to these nationalist interpreters of Alevilik, it was corrupted into a heresy (even küfr) whose believers do not practice Sunni rituals, think Ali is God, share their wives, easily become Communists, and the like.

The prevailing conditions in Turkish society today foster nationalistic tendencies. There is the military war going on in the south-east since the early 1980s during which thousands of Turkish soldiers have been killed. Society witnesses almost every night on television their burial ceremonies and the screams and cries of their families who are left behind, ${ }^{30}$ including many women and children. There is the recent capture of the PKK leader Öcalan and the pro-Öcalan stand of some European countries. There is the ongoing ethnic cleansing of the Muslims in the Balkans. All this has been intensifying the nationalist feelings of the Turkish people. In this atmosphere, it is not surprising to find some Turkish speaking Alevis joining the nationalist group by emphasizing their Turkishness, and to this group we can even include some Kurdish speaking Alevis. ${ }^{31}$ Ordinary Alevi Kurds tend to feel threatened by the strong feelings against Kurds in society where Kurds are stigmatized by associating them with the 'PKK terrorists', and some tend to suppress their Kurdish identity and distance themselves from those Alevi Kurdish groups who stress their Kurdishness; they instead emphasize their integration into Turkish society.

In brief, given the contemporary high credit accorded Turkish nationalism and patriotism, the nationalist call for prioritizing 'our Turkish identity' (putting it even before death) above all other forms of communitybelonging finds an affirmative echo in society, as well as in many political groups. On the other hand, given the historical enmity of ultra-nationalists against Alevis as witnessed in the Maraş (1979) and Çorum (1980) events, and also in the more recent Sivas ${ }^{32}$ (1993) and Gazi-Istanbul ${ }^{33}$ (1995) incidents these reactions or attempts to disintegrate Alevi differences do not stand much chance in Alevi political groups. 
We distinguish 'the Crude-Marxist/Atheist Claims on Alevilik' group from the liberation theology approach of the Kurdish Alevilik or the socialistic/social democratic approach of some of the Alevis from the Cem Vakfı group, although the three groups sometimes share a Marxian terminology. The crude Marxist-atheist approach, not being very much credited by the Alevis, is the most marginal of the three Leftist versions. Alevilik is similarly seen as an egalitarian ideology, and Alevis as a historically anti-systemic, socialist people. Beginning from Ali's times, and coming to Babai revolts and Sheikh Bedreddin, all revolting peoples are coded as Alevis, and this results in many anachronisms. There is stress on the class character of all those historical struggles, and there is also an antireligious, atheistic overtone, a decisive reluctance against accepting Alevilik as a religious syncretism.

The distinguishing feature of this group is its criticism of the religious, conservative, anti-modernist aspects of Alevilik, calling for a disenchantment of the teachings and rituals, and the filtered version will be a folkloric, egalitarian 'native' socialism. A recent book is the best example of this trend in which it is argued that Ali was a practicing Sunni and was as cruel and bloodthirsty as other fundamentalist followers of the Islamic Sharia. The author argues that Alevi Sharia was as bad as the Sunni one, and he ends up with offering an 'Alevilik without Ali'.$^{34}$ With this call for the abolition of the 'cult of Ali' from Alevilik, a hot debate has begun where some Alevi Kemalist-traditionalists have reacted against the anti-religious interpretations of Alevilik. An edited book is written as an answer to the author's thesis ${ }^{35}$ which challenges and rejects his ideas, humiliating him and the book, and attempting to show that the book is full of contradictions and insufficient historical analysis. It seems that as long as religion and tradition are outwardly rejected for the sake of revitalizing a 'politics of distribution' (in a Marxist vein), such attempts will be politically insignificant.

Sunni Islamists, be they politicians or academics (or both), do not stand much chance within Alevi politics of gaining support for their views. Nevertheless, they are potentially more significant than the previous four groups, that is, they are more likely to produce stronger effects within Alevi religious debates. Today, Sunni Islamists are generally assimilative in their approach to Alevis, and they mainly follow three strategies: they define it as a 'subculture' and hence do not recognize its theological significance; they regard it as a mere religious sect and hence suppress it by claiming that the Directorate of Religious Affairs is above all sects; and finally they claim that there are 'good' and 'bad' Alevis, and in the latter group are included 
atheists, Marxists, and the like, who tend to use Alevilik as a tool. ${ }^{36}$ When they are not implicitly assimilative, Sunni Islamists tend to label ordinary Alevi believers as ignorant, naive, innocent Muslims who have somehow been pushed out of the 'true path'. They strongly argue against the Alevi belief that the Koran was changed by the political opponents of Ali after Mohammed's death, and they harshly criticize Alevis' rejection to practice namaz and other Sunni religious services. This increases the tension between the Alevi and Sunni communities.

It should be noted that information on Alevilik is totally absent in Koran courses, Imam-Hatip schools, Higher Islam Institutes, theology faculties, and even the compulsory religious courses offered in the official education system. All of the religious institutions associated with the state (beginning from the Directorate of Religious Affairs) are Sunni-dominated, especially by the Hanefi version of Sunnism. This, while on the one hand it may socialize the Alevi youth into the Sunni sect, may on the other hand create strong reactions in the Alevi community.

From time to time the former Welfare Party (WP) made sympathetic calls to Alevi communities and invited their 'religious brothers' to the party ranks. The party's economic promises and populist policies, along with the diverse influences of the city, have lured some of the Alevis, especially the economically disadvantaged ones living in squatter settlements, into voting for them. However, especially after the Sivas event in 1993 and its aftermath which witnessed the pro-event reactions of the Sunni Islamist media and Sunni politicians, as well as the anti-Alevi and/or assimilationist declarations of the high-ranking WP members, a great majority of Alevis today, regardless of their political dispositions, have become highly suspicious of the pro-Sunni politics.

In brief, considering the amount of theological and political tension between the two communities, it may sound meaningless to discuss the place of Sunnism and the relevance of Sunni-biased scholars within Alevi politics. However, in the case of Sunnism or Orthodox Islam, while most of what is written by Sunni-biased authors lacks intellectual elaboration (in terms of credibility according to social scientific standards, for example), the religious references and symbolic structure made use of by Sunni Islamists are not totally irrelevant to Alevilik. There is an undeniable parallelism because of the fact that the two mezheps (sects) share a common religious history and a common geography, that is, Anatolia, and this connection, along with its conflict and reconciliation processes, is enough to create an effect within Alevi politics, in terms of both constructing a different Alevilik and attracting various Alevi reactions which still lead to different Alevilik(s). 
After the Cem Vakfi group, 'the Alevilik as Liberation Theology' group represents the second most powerful Alevi political movement, and is similarly organized around an association, namely, Pir Sultan Abdal Kültür Dernekleri (PISA, Pir Sultan Abdal Cultural Associations), and a journal, Pir Sultan Abdal Kültür ve Sanat Dergisi (Pir Sultan Abdal Journal of Culture and Art). There are also many small organizations, as well as radical leftist journals like Kervan and Zillfikar close to the group which are ideologically supportive of Kurdish nationalism.

A defining characteristic of this political group is the use of a Socialist discourse which is very different from the atheist claims summarized above. Alevilik is defined outside of Islam as a non-Islamic quasireligious movement prophesying emancipation. In this group we can distinguish Social Democratic writers promoting secular ideas and those traditionalist Alevis with religious dispositions who try to resurrect a divine tradition against Sunni threats. On the other hand, the supporters of the Kurdish movement within the group focus on Kurdish and Zaza mythologies and Mazdaist influences on Alevilik, mixing Socialism with a Mazdaist-Alevi liberation theology. They tend to emphasize their Kurdishness rather than their Aleviness without rejecting the latter. They draw upon Kirmanci and Zaza languages, and by merging these cultural elements with the history of both Kurdish or non-Kurdish popular resistance movements (from Babai revolts in the Selcuk era to the Dersim revolts in the Republican era), they construct an Alevilik to be adopted by the Kurdish (or Zaza) population.

Consequently, Alevilik as liberation theology is rhetorically mobilized in defence of Turkish and Kurdish people, and many aspects of contemporary Turkey are criticized from a Marxian point of view. The Turkish Leftists within the group, who defend a popular-secular Alevilik against the conservative Alevilik which is separate from Islam, are more powerful in the group, but they are by no means hostile to the cause of Kurdish Alevis. On the other hand, there are some extremist elements in the group, namely, the sympathizers of the illegal Kurdish guerrilla movement, and in the final analysis, these constitute an important barrier to the group's general claims for popular support and political legitimacy. For example, such declarations may be encountered:

Alevilik is a religious belief which formed and proliferated within the process of development of Islam among the peoples of the Middle East, Mesopotomia and Anatolia. It spread more particularly among the impoverished nomadic and semi-nomadic Kurdish and Turkmen tribes. While Sunnilik, the predominant Islamic right-wing interpretation and evolution, was preferred by the dominant feudal 
classes and states, Alevilik was the religious belief held by the oppressed classes whose interests were totally opposed to those of the ruling classes and states against whom they conducted a perpetual struggle. This was, in effect, a class war that assumed a religious form and was conducted under the guise of a struggle between different faiths and religions. Alevilik was a rebellion, a resistance, a flag of liberation raised against the ruling classes who, with Sunnilik, the dominant form of Islam, adopted a feudal structure and established centralised states and empires. ${ }^{37}$

As Bruinessen ${ }^{38}$ correctly points out, unlike the majority of Turkish Alevis, Kurdish Alevis were never at peace with the Kemalist regime. He tells that the Dersim revolts of 1937-38 were Alevi as well as Kurdish revolts where both Turkish Alevi villagers and Zaza Alevis fought together against the pacification policies (leading to violent massacres) of the Ankara government. On the other hand, there is the historical tension between Sunni Kurdish tribes (more powerful and crowded) and Alevi Zaza tribes, and the PKK's pro-Sunni strategies have led to identity shiftings among these Alevis: "Alevi, but unlike the Turkish Alevi, Zaza or Kurdish, but unlike the Sunni Zazas or Kurds'. ${ }^{39}$ Although a certain trend in the Pir Sultan Abdal journal supports anti-statist yet Republican ideas, being mainly opposed to the right-wing - and 'establishment' - policies of the Cem Vakfi, ambiguities within the group, with regard to how Alevi liberation is to be accomplished, render the group less powerful than the Cem Vakfi which is also in direct opposition to PISA (Pir Sultan Abdal Cultural Associations), the former being more nationalist, strongly pro-Kemalist, and led by betteroff Alevis.

The 'Kemalist-Traditionalists and Republican Alevilik' group, formed around the Republican Education and Culture Centre Foundation (RECC Foundation, or the Cem Vakfi) and the monthly journal Cem, is economically and politically the most powerful and perhaps the most popular Alevi organization. Within the foundation, there are Left-inclined writers, intellectuals, artists and academics who do not place much stress on religious aspects of Alevi and Bektashi orders, but point out their positive relations with Kemalism, Enlightenment, Westernization, liberalism, religious freedom, toleration and the like. The Foundation's core body consists of Alevis (that is, those who were born Alevis), yet the Foundation attempts to open itself up to Sunnis through Bektashilik. ${ }^{40}$ It further accepts into it those secularist Sunnis who support Kemalist ideals. Here, in order not to give a wrong image of society, it should be pointed 
out that historically secularist Sunnis, often called Kemalists, are devoted to these concepts as strongly as Alevis are. Thus an image of society in which there is a split between Sunnis and Alevis, Alevis defending secularism and Sunnis Sunni Islamism, is totally wrong. Along with this group there are former dedes, dede-babas, or descendants of such AleviBektashi religious leaders who try to institutionalize an Alevilik with its fiklh theory, its written theology, legal academies, schools and religious institutions (cem houses). This trend totally agrees with the intellectual trend in building an Alevi barrier in front of the rising Sunni Islam, but unlike the PISA group, it defines a secularized version of Alevilik within Islam.

Rather than seeing Alevilik as a Socialist liberation ideology, the mainstream writers of the group seem to accept that the Alevi-Bektashi religious structure today is a syncretism which unites many belief systems from Shamanism to Sufism. Although we can encounter from time to time 'Socialistic' interpretations (Alevilik as resistance, as struggle against the ruling class), there seems to be a general consensus within the group to construct an institutionalized religion with its own version of Koran. According to this group, the Koran today is incomplete and adulterated: during the era of Caliph Osman, many passages referring to Ali were excluded from the compilation of the holy book.

The Cem Vakfi is a devoted supporter of the Kemalist principles, the Republican regime, and Social Democratic policies (there is a considerable but not total support to the CHP, which will most probably be turned to the DSP, the Democratic Left Party, in the current political situation). The foundation's dislike of Sunni Islamism is totally in line with the Army's (and the parliamentary centre's) policies, and the foundation's lobbies work to bring its own version of Alevism-Bektashism to an equal level with mainstream Sunnism.

One of the most important political manoeuvers of the foundation is its pressure on the government and parliament for Alevi representation in, and equal funding, from the Directorate of Religious Affairs (Diyanet), ${ }^{41}$ and additional funding from the state for the construction and opening of new cem houses. This strategy is closely parallel with the group's studies on making Alevism-Bektashism a strong sect as powerful as the current organizational structure of Hanefi Sunnism. This demand is criticized by other Alevi groups, which defend the total abolition of the Directorate because it is, as they argue, against the principle of laicism. If we consider the close connections established by the Cem Vakfi within the state (plus the implicit support from the Army), the foundation's acceptance of the legitimacy of the Directorate is understandable. 
We have covered contemporary Alevi political positions in their diversity, positing that the claim of a singular Alevi identity and a singular Alevilik is misleading. The numerous debates, blamings and criticisms within Alevi politics today show that there is a constant struggle over the definition of the Alevi identity, over its boundaries. The aim in these debates is not only to exclude Sunni, atheist and nationalist interpreters; those Alevis who are 'authorized' to speak about and politicize Alevilik also try to show that, even among themselves, 'we' are right but 'they' are wrong. Thus, within Alevi politics, different groups constantly produce definitions both for 'other' Alevilik(s) and for themselves, trying to establish a monopoly over the right definition.

In this competition among the different Alevi groups, we hold that Republican Alevilik, for now, has the upper hand in the political sphere because of the delicate balances it has established. First of all, the group seems to have articulated itself with a highly legitimate political power, the Army and the Kemalist legacy represented by it. This alliance with a power outside Alevi politics, based on their commitment to secularism, allows the group to shift between 'Leftist' and 'Rightist' maneouvers. On the one hand, they assume a progressivist, secular, egalitarian, tolerant, and SocialDemocratic stance and try to gain popular support from the Alevi population, as well as from the Social Democratic Sunni population; on the other hand, they affirm the Turkish state as it is, avoid direct conflict with its institutions, ally with the National Security Council policies against Sunnism (while never losing touch with certain groups of the Sunni community for pragmatic reasons), and never clash with 'defensive nationalism'.

What other groups further lack is the balance the Republican Alevis have established between religious and secular aspects. In the case of mysticalIslamic Alevilik, building rhetoric on a highly religious base fails to give a worldly account of contemporary economic and social events which is meaningful with regard to the realities of everyday life; and in the case of Sunni or Shiite attempts to penetrate, the content of the Alevi religious rhetoric, along with historical events, are rejected. These versions of Alevilik are 'irreligious' according to the Alevi majority. It is also impossible for the proponents of pure rationality, atheism or agnosticism to touch the popular 'spirit' (this time there is a lack of religiosity and tradition); thus their Alevilik(s) are bound to remain elitist, attractive only to a small group of believers. In the case of Alevi Liberationism organized around the PISA, although its structure is similar to its rival - the Republican Alevilik - it fails to find a 'way out' because the political stance it assumes is openly against state interests. Moreover, there is another tension between pro-Turkish and pro-Kurdish versions of Alevi Liberationism within the group. 
So whither Alevi politics? An affirmative 'politics of recognition' is likely to prevail. This seems to be led by the Cem Vakfi or a similar-minded political group, whereas a transformative 'politics of redistribution' to abolish the class character of Turkish society, along with oppression emanating from identity conflict, seems to be politically weak..$^{42}$ From the perspective of general power struggles in Turkey at the turn of the twentieth century, there are three points which justify an affirmative (that is, allied with the republican 'establishment') rather than transformative Alevi politics.

First, it can be argued that after the rise of Sunni political Islam and its gaining of considerable electoral power, along with the influence of the Army-sponsored campaign against Islamism (gaining momentum after the National Security Council meeting on 28 February 1997) which revived Kemalist images of secularism, modernism and progress, the Alevi population allied with the secularist Sunnis and rapidly developed itself into a 'counterforce' against Sunnism. Therefore, Alevi politics tended to lay stress on its difference (and sometimes different within Islam, not different from Islam) vis-à-vis the rising Sunnism, abstaining from challenging the Republic's political-economic institutions, and offering a reformative project for some of its religious and cultural institutions.

Secondly, this consolidation attempt also had a mutual relationship with the Turkish state's struggle against PKK activities. As we have seen, both central Right and central Left Alevisms reproduce the affirmative discourse of their politics in their attempt to show that there is no actual Alevi-Sunni 'split', that religious groups in Turkey are united under one Flag, one Book, one Vatan, and one State. The strong nation-wide nationalist feelings after the capture of Öcalan strengthened the calls from the Turkish civil society for unification and national solidarity, leaving space only for a politics of recognition for the Alevis .

Third and last, the space for oppositional and transformative politics (especially for the Social Democratic and Socialist Left) has further narrowed after the 18 April elections: six Left-wing parties (excluding 'centre Left' parties $)^{43}$ could collect only about 6 per cent of the votes and the 'Social Democratic' CHP (the Republican People's Party) could not enter the parliament. On the other hand, ultra-nationalist MHP gained 18 per cent of the votes, emerging as the second party, after the 'Kemalistnationalist' DSP's (the Democratic Left Party) 22 per cent. Although it is yet to be seen what kind of 'Leftism' will DSP perform, the current scene seems to justify our claim in the near future: Alevi politics will continue to be affirmative in reducing, but not totally effacing, the ethnic and 
religious differences included in its space to 'harmonious parts of a fixed whole'.

Thus, the Republican Alevis and their foundation the Cem Vakfl, we think, are likely to gain control over the proper definitions of the 'Alevi', the contents and histories of Alevilik, and what the legitimate religious practices are. On the other hand, the PISA group is far less likely to gain the upper hand, with its less religious, more Socialist rhetoric, a rhetoric which feeds on a Marxist core. It is questionable whether the group will manage to mobilize subaltern Alevis without getting rid of its anti-systemic overtones. Given that in today's political context the winds of nationalism are blowing harder than ever, any political movement with explicit anti-systemic dispositions, especially Socialist discourses (even though they have nothing to do with terrorism), will tend to receive a chauvinistic rejection from the ordinary citizen.

When it comes to the question of whether the recognition of Alevi difference(s) will aid the creation of a more pluralistic political system, we have some reservations. Today the formation of a class structure within the Alevi population makes it problematic to claim that there is the Alevi community whose major problem is its oppression as a people because of their sectarian beliefs. Thus, an identity politics which limits itself to the cultural and religious aspects of Alevilik(s), as is the case of the Republican Alevis, is bound to fail to address the contemporary economic problems of the Alevi (ranging from access to urban services and housing to access to employment opportunities). The Republican Alevis fail to address the erosion of Alevi influence in local politics, and as a result, the problem of downward mobility and economic deterioration which Alevis, and particularly those living in gecekondu settlements, are experiencing. Without rejecting the fact that the recognition of the Alevi identity in politics is a political gain in itself, we are still skeptical about the possible contributions of Alevi politics to Turkish democracy, as shaped under current political conditions. Without acknowledging the class dimension, as well as the ethnic issue, Alevi politics cannot be fully democratic.

\section{NOTES}

1. We have chosen to use the Turkish term Alevilik instead of Alevism or Aleviness because it covers both its ideological construction as a social movement and its social identity aspect.

2. Reha Çamuroğlu, 'Alevi Revivalism in Turkey', in T. Olsson, E. Özdalga and C. Raudvere (eds.), Alevi Identity: Cultural, Religious and Social Perspectives (Istanbul: Swedish Research Institute, 1998), p.84; Harald Schüler, Türkiye'de Sosyal Demokrasi: Particilik, 
Hemşehrilik, Alevilik (Istanbul: İletişim, 1999). The head of the Republican Education and Culture Centre (Cem Vakfi) makes a similar estimation in the symposium organized by the Centre where the restructuring of religious services was discussed ('Din-Devlet İlişkileri ve Türkiye'de Din Hizmetlerinin Yeniden Yapılanmasì Sempozyumu', 26-27 March 1996 (Istanbul: RECC Publications, 1998), p.32). Ayşe Ayata ('The Emergence of Identity Politics in Turkey', New Perspectives on Turkey, no.17, 1997, p.30) writes that about 25 per cent of Ankara's and 15-20 per cent of Istanbul's population is Alevi.

3. See, for example, Çamuroğlu, 'Alevi Revivalism in Turkey'; Esat Korkmaz, Alevilere Saldirlar (Istanbul: Pencere, 1997).

4. For an introductory discussion, see Karin Vorhoff, 'Academic and Journalistic Publications on the Alevi and Bektashi of Turkey', in T. Olsson, E. Özdalga and C. Raudvere (eds.), Alevi Identity: Cultural, Religious and Social Perspectives (Istanbul: Swedish Research Institute, 1998), pp.23-50.

5. Çamuroğlu, 'Alevi Revivalism in Turkey', pp.79-84.

6. Krisztina Kehl-Bodrogi, 'Introduction', in K. Kehl-Bodrogi, B. Kellner-Heinkele and A. Otter-Beaujean (eds.), Syncretic Religious Communities in the Near East (Leiden: E.J. Brill, 1997), p.xiv.

7. Sema Erder, Kentsel Gerilim: Enformel Ilişki Ağlari Alan Arastırması (Istanbul: Um:Ag, 1997), p.177.

8. Among the younger generation of Alevi Kurds who grew up in the city, there are those who tend to bring their Kurdishness to the fore and criticize strongly the Sunni-Turkishness emphasis of the state. In the international arena, Kurdishness rather than Aleviness has the potential to mobilize the public, and hence Kurdishness is emphasized in this context. See Günter Seufert, 'Between Religion and Ethnicity: A Kurdish-Alevi Tribe in Globalizing Istanbul', in A. Öncü and P. Weyland (eds.), Space, Culture and Power: New Identities in Globalizing Cities (London and New York: Zed, 1997), p.172.

9. Krisztina Kehl-Bodrogi, 'Tarih Mitosu ve Kollektif Kimlik', Birikim, No.88 (1996), pp.52-63.

10. The stance against Marxist claims on the oppositional-transformative aspects of popular Alevilik is a never-ending debate. While some Social Democrats like to define their Alevi identity as a secular, non-Islamic, progressivist philosophy, those Alevis who wish to see Alevilik as a sect within Islam possess more nationalist/pro-systemic dispositions. For a recent attack on Marxist interpretations, see Ali Aktaş et al., Alisiz Alevilik Olur Mu? (Istanbul: Ant, 1998).

11. Seufert, 'Between Religion and Ethnicity', p.173.

12. See, for example, Fuat Bozkurt, 'State-Community Relations in the Restructuring of Alevism', in T. Olsson, E. Özdalga and C. Rauder (eds.), Alevi Identity: Cultural, Religious and Social Perspectives (Istanbul: Swedish Research Institute, 1998), pp.85-96.

13. Erder, Kentsel Gerilim, pp.136-43.

14. Ayata, 'The Emergence of Identity Politics in Turkey', p.67.

15. Following the bombing of a kahvehane attended by Alevis in a gecekondu (squatter) neighbourhood populated by an overwhelming majority of Alevis (Kurdish and Turkish) by some unidentified provokers, during which an elderly Alevi dede was killed, a large crowd of armed Alevis (mostly young people mainly from gecekondu neighbourhoods) gathered to protest against the attack, and violent encounters between the Alevi group and the police took place. The insurrection ended with the killing of 11 protesters by police bullets. See, Aliza Marcus, "Should I Shoot You?" An Eyewitness Account of an Alevi Uprising ini Gazi', Middle East Report (April-June 1996), pp.24-6.

16. A reprint of the manifesto can be found in Riza Zelyut, $\ddot{O}_{z}$ Kaynaklarına Göre Alevilik (Istanbul: Anatolian Culture Publications, 1990).

17. Tord Olsson, 'Epilogue: The Scripturalization of Ali-Oriented Religions', in T. Olsson, E. Özdalga and C. Raudvere (eds.), Alevi Identity: Cultural, Religious and Social Perspectives (Istanbul: Swedish Research Institute, 1998), p.200. 
18. Mehmet Kurkınct, Alevilik Nedir? (Istanbul, 1987).

19. Kutluay Erdoğan, Alevilik-Bektaşilik (Istanbul, 1993); Mehmet Eroz, Eshi Türk Dini (Gök Tanr Inanct) ve Alevilik-Bektaşilik (Istanbul: Turkish World Series Foundation, 1992).

20. Rıza Algül, Aleviliğin Sosyal Mücadeledeki Yeri (Istanbul: Pencere, 1996); Selman Çıranoğlu, 'Türkiye'de Demokratik Siyasi Bir Mesele: Alevilik', in C. Şener (ed.), Alevilik Üstüne Ne Dediler? (Istanbul: Ant, 1990); Riza Zelyut, Aleviler Ne Yapmall? Sehirlerdeki Alevilerin Sorunlart-Çözümleri (Istanbul: Yön, 1993).

21. For example, Oral Çalışlar, Hz. Ali-Muaviye Çatışmast: Islamin Doğuşu ve Illk Ayrtıklar (Istanbul: Pencere, 1997); and İthan Selçuk, Enel Hakk'ın Hakkl (Istanbul; Cumhuriyet Books, 1998).

22. Martin van Bruinessen, 'Kurds, Turks and the Alevi Revival in Turkey', Middle East Report (July/Sept. 1996), pp.7-10; Kehl-Bodrogi et al., Syncretic Religious Communities in the Near East; Irene Melikoff, Uyur Idik Uyardllar: Alevilik-Bektaşilik Araştırmalart (Istanbul: Cem, 1993); Ragnar Naess, 'Being an Alevi Muslim in South-Western Anatolia and Norway: The Impact of Migration on a Heterodox Turkish Community', in Thomas Gernholm and Ingvar G. Lithvan (eds.), The New Islamic Presence in Western Europe (London and New York, 1988); Olsson et al., Alevi Identity: Cultural, Religious and Social Perpectives; and Orhan Türkdoğan, Alevi-Bektaşi Kimliği: Sosyo-Antropolojik Araştırma are the best known (and frequently cited) examples of such work.

23. Reha Çamuroğlu, Tarih, Heterodoksi ve Babailer (Istanbul: Metis, 1992); Abdülbaki Gölpınarl, Tarih Boyunca Islam Mezhepleri ve Şiilik (Istanbul: Der, 1979).

24. Faruk Bilici, 'The Function of Alevi-Bektashi Theology in Modern Turkey', in T. Olsson, E. Özdalga and C. Raudvere (eds.) Alevi Identity: Cultural, Religious and Social Perpectives (Istanbul: Swedish Research Institute, 1998), pp.51-62.

25. Ahmet Yaşar Ocak, Türk Suflitigine Bakışlar: Türkiye'de Tarihin Sapttrlması Sürecinde (Istanbul: İletişim, 1996), pp.191-223.

26. Bilici, 'The Function of Alevi-Bektashi Theology in Modern Turkey', p.56.

27. Ruşen Çakır, Ayet ve Slogan: Türkiye'de Îslami Oluşumlar (Istanbul: Metiş, 1990), pp. $155-63$

28. Bilici, 'The Function of Alevi-Bektashi Theology in Modern Turkey', p.53.

29. Ocak, Türk Sufiliğine Bakışlar, p.151.

30. 'Tears and fury' is the frequently used headline on the TV news while presenting the burial ceremonies.

31. On the news of 7 May, there was the burial ceremony of an Alevi Kurd 'Turkish' soldier killed by the PKK. His ceremony was held first in a mosque, followed by a ceremony in a cem house in Istanbul. The martyr's mother screamed in Kurdish her desperate grief.

32. Thirty-seven Alevis were burnt to death in a hotel in Sivas by radical Sunnis in 1993 when some leftist intellectuals, including many Alevis came together to celebrate the Fourth Pir Sultan Abdal festivity. See, for example, Zeki Coşkun, Aleviler, Sünniler ve Öteki Sivas (Istanbul: İletişim, 1995).

33. See, Marcus, "'Should I Shoot You?"”, pp.24-6.

34. Faik Bulut, Alisiz Alevilik (Ankara: Doruk, 1997).

35. Ali Aktaș et al., Ali siz Alevilik Olur Mu?

36. Bilici, 'The Function of Alevi-Bektashi Theology in Modern Turkey', p.60.

37. Ibid., p.52.

38. Martin van Bruinessen, 'Aslını İnkar Eden Haramzadedir!: The Debate on the Ethnic Identity of the Kurdish Alevis', in K. Kehl-Bodrogi et al. (eds.), Syncretic Religious Communities in the Near East (Leiden: E.J. Brill, 1997), pp.1-22.

39. Bruinessen, 'Aslını İnkar Eden Haramzadedir!', p.17.

40. Alevilik is an ascribed status, whereas Bektashilik is an achieved one. Thus, you can be an Alevi only if you are born an Alevi, but you can be a Bektashi if you have successfully fulfilled its criteria. 
41. For a useful summary of the 'Diyanet Debate', see Battal Pehlivan, Aleviler ve Diyanet (Istanbul: Pencere, 1993).

42. We borrow the analytical distinction between 'politics of recognition' and 'politics of redistribution' from Nancy Fraser, 'From Redistribution to Recognition? Dilemmas of Justice in a "'Post-Socialist" Age', New Left Review, Vol.212 (July-Aug. 1995), pp.68-93.

43. Those are: HADEP (People's Democracy Party), ÖDP (Freedom and Solidarity Party), IP (Workers' Party), EMEP (Labour's Party), SIP (Socialist Power Party) and DBP (Democratic Peace Party). 